\title{
THE EFFECT OF THE TRACTION THERAPY ON PATIENTS WITH LUMBAR DISC DISEASE
}

\author{
Mihaylova Mariyana, PhD, Associate Professor; Medical University of Varna, Faculty of Public \\ health, Department of Physiotherapy, rehabilitation, thalassotherapy and occupational diseases, \\ Bulgaria, ORCID ID: https://orcid.org/0000-0001-5130-9743
}

DOI: https://doi.org/10.31435/rsglobal_conf/30032021/7473

Abstract. The goal of this research is to examine the efficiency of a set of physical factors with the inclusion of traction therapy in treating lumbar static and dynamic pain and the opportunities to influence the quality of life of patients with lumbar disc disease (LDD).

100 patients with lumber disc disease participated in the clinical study. They were equally divided into a control group (CG), which has been treated with basic therapy (LFMF and IFC) and experimental group (EG) where traction therapy was part of the treatment protocol. For evaluating the effectiveness of the treatment was used quantitative assessment for static and dynamic pain and the quality of life before and after the treatment.

Results of both treatment protocols have statistically significant effect $(p<0,001)$ in reducing low back pain and improving the quality of life. In comparison between the two groups, EG has a statistically significant $(p<0,001)$ advantage over the $C G$.

The inclusion of extension therapy in basic physical therapy gives excellent results, contributes to a more significant reduction of pain and improves the quality of life of patients.

Keywords: lumbar disc disease (LDD), physical therapy, traction therapy, LFMF (low-frequency magnetic field), Interferential current (IFC).

Introduction. One of the most common reasons for hospitalisation is the back pain (12). In many cases the cause lies in degenerative-dystrophic changes in the vertebrae $(6,7,13)$. Research shows that roughly $80 \%$ of the vertebral pain syndromes originate from the lumbar region $(7,13,14)$. This is due to the area taking the biggest load while moving or resting $(3,6)$. The physical therapy has mandatory part of the complex treatment of low back pain, because of its proven effectiveness. Recovering the statics and kinetics of the vertebrae is achieved mostly through physical therapy means $(5,8)$. Lots of research shows that the inclusion of traction therapy to the treatment protocol offers faster improvement of both vertebral and neurological syndromes of the disease $(2,4)$. This method is the only one with mechanical effect, which helps the removal of disco-radicular issue, causing the neurological materialisations of the disc disease $(4,8)$.

The treatment of back pain through traction is known since the age of Hippocrates (17). The method is scientifically proven in the XIX century by the works of Charcot, Mitchell etc. Nowadays, traction therapy offers high efficiency potential, but only if using a rigorous protocol in regards to the therapy itself as well as following specific regime after the procedure $(2,4)$. Traction therapy eases the load on intervertebral disc, back joints, normalizes the interjoint fluid exchange, improves the blood circulation in tissues and their metabolism. This leads to significant reduction of pain and improves the mobility of the lumbar mobile segments $(4,8,9)$.

One of the modern ways to apply traction therapy is the impulse traction therapy using the apparatus of the Dutch company Enraf Nonium - Eltrak 471, which allows traction therapy in both impulse and constant mode.

The goal of this paper is to examine the efficiency of a set of physical factors with the inclusion of traction therapy in treating lumbar static and dynamic pain and the opportunities to influence the quality of life of patients with lumbar disc disease (LDD).

Subject and methodology:

100 patients with lumber disc disease participated in the clinical study. They were divided equally into two groups. The experimental group (40+4,5y) consisted of 18 women and 32 men, while the control group $(41+4,9 y)$ had 17 women and 33 men. Data from CT scan and NMR shows that the patients has disc protrusions and hernias. The lumbar disc pathology in 10\% of the cases was in L3-L4 level, $25 \%$ in L4-L5, 40\% in L5-S1 and the remaining 35\% in more than 2 levels. 
Main criteria for inclusion of patients in the study: age 18-55; presence of low back pain; proven degeneration of the spinal discs in the lumbar region - disc protrusions and hernias; onset of the disease no more than two years, no surgical treatment

Criteria for exclusion of the study: patients bellow 18 years of age; individuals with a pacemaker, neoplasm, infectious or other diseases, which are contraindicative of conducting physical therapy; presence of severe spinal pathology such as tumors, compressive fractures, infections, severe arthritic changes (bone bridges) etc.; presence of symptoms of root compression-Lassegue below $30^{\circ}$; reduced reflexes and senses, paralysis and paresis; pregnancy; rhythmic pathology; surgery in the lumbar region.

The basic treatment protocol consisted of interferential current (IFC), using the bipolar method and low-frequency magnetic field (LFMF). Through randomization, the patients were equally divided into two groups - a control group (CG), which has been treated with basic therapy (LFMF and IFC) and experimental group (EG) where traction therapy was also part of the protocol. The EG protocol consisted of the following procedures in their sequence: Magnetic therapy with the following parameters: 16000 $\mathrm{A} / \mathrm{m}, 1 \mathrm{~Hz}, 0,2 \mathrm{~s}, 15-20$ mins, 10 procedures; Bipolar IFC by paravertebral positioning of the electrode levels (L1-S1) with parameters $90-130 \mathrm{~Hz}-15$ mins; Traction therapy for $20 \mathrm{mins}$; Rest for 2 hours in Williams posture (upper body laying down, legs elevated on a stool folded in $90^{\circ}$ in the knee and tight joint) in order to turn the lumbar lordosis into kyphosis and unload the pressure of the lumbar spine; After the procedure, the patient puts an orthopedic corset on his lower back; Number of procedures: 10.

The pulling pressure is dependent upon the level of degenerative-dystrophic changes and the pain syndrome, the stage of the disease as well as patient's weight. Traction treatment is performed in an impulse manner, which reduces the risk of developing spinal imbalance.

To track the effect of the treatment were used the following clinical methods: For subjective assessment of the pain before and after the treatment - the static scale of Borg and the dynamic scale of Merl d'Aubigne, following T. Todorov's protocol (11). The quality of life assessment is done by the Roland-Morris test (18).

Results. Before the treatment the average values of the Borg's scale are very close, because of the randomized selection of the group's members. The comparison between the group's results by Paired Samples T-test, one and three months after the therapy shows a statistically significant $(\mathrm{p}<0,001)$ superiority of the EG (Figure 1$)$.

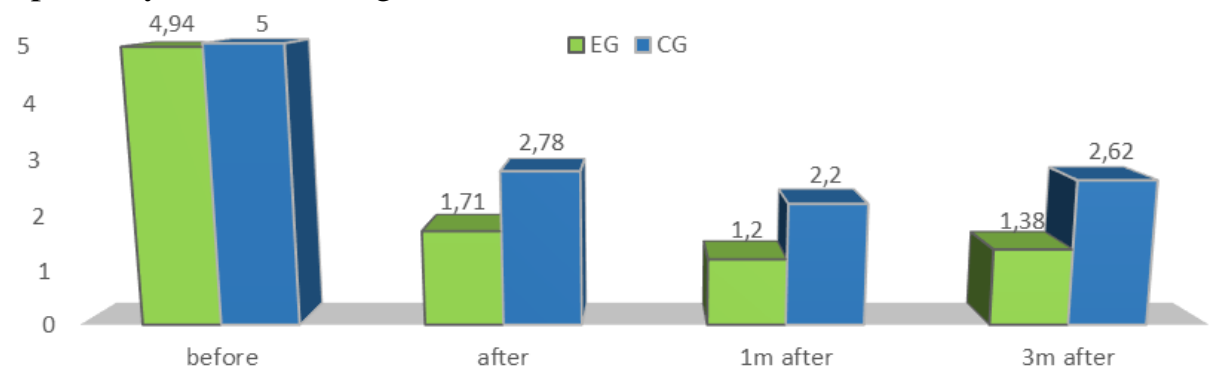

Fig. 1. Assessment of the static pain through Borg's scale

After analyzing the data of average values for the dynamic pain, through the Merl d' Aubigne scale in both groups a statistically significant improvement was found in both groups. However, the results in the EG have an average value of 1,12 , compared to 2,12 in the CG, which is a statistically significant difference in favour of the EG (Figure 2).

$\square \mathrm{EG}$ =CG

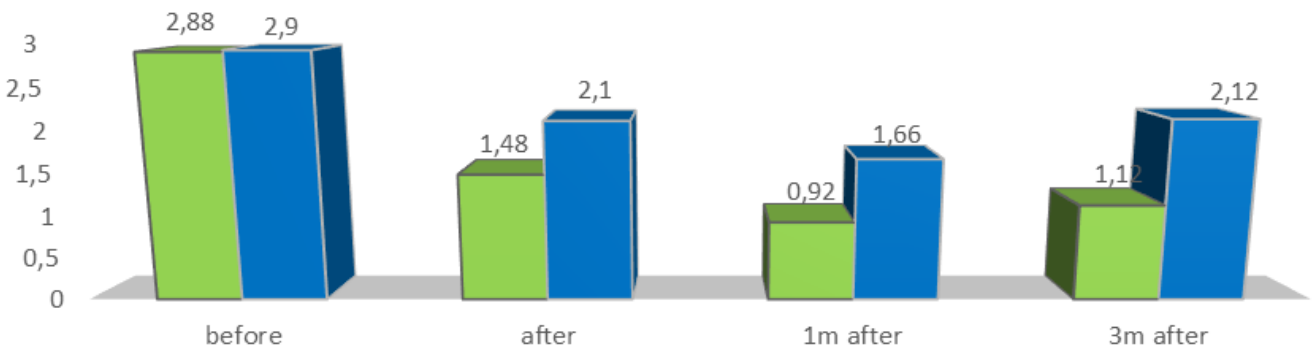

Fig. 2. Assessment by the modified scale of Merl d' Aubigne for dynamic pain 
The analysis of the results of both groups from RMDQ shows that both groups register statistically significant improvement. The results in the EG are 12,18 and 4,44 before and after the treatment, respectively $(\mathrm{p}<0,001)$. At the same time, CG's results are 12,16 before and 5.82 after the treatment $(\mathrm{p}<0,001)$. This proves the improvements regarding the quality of life of the patients with superior results of those in the EG. The latter group keeps improving after the therapy with RMDQ scores of 4,02 and 4,2 one and three month after the treatment, respectively. These results reveal the lasting effect of the complex treatment with traction therapy. The CG's results also show slight improvement one month after the treatment with a score of 5,52 and 5,68 after three months. When comparing the results between the two groups, the difference is statistically significant $(p<0,001)$ in favor of the EG (Fig. 3).

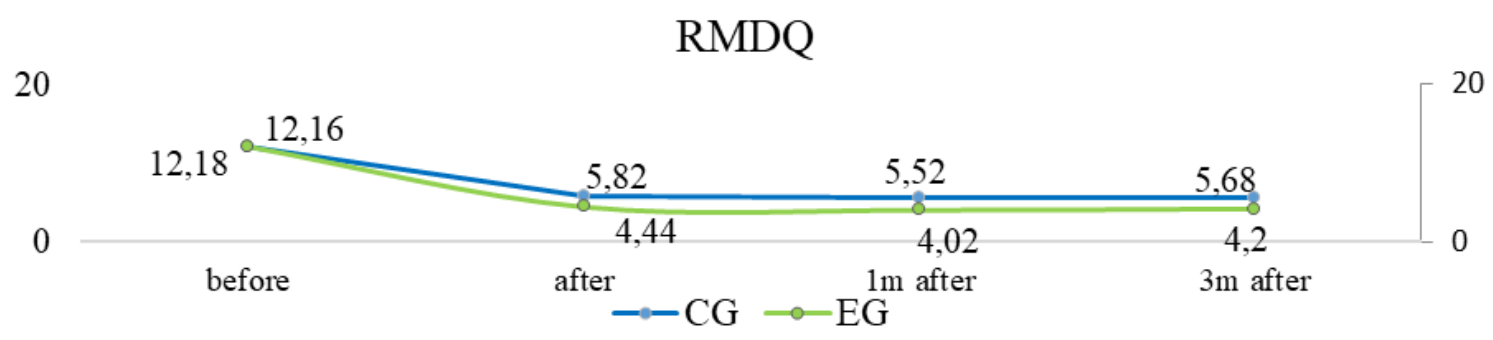

Fig. 3. Dynamics of the results from $R M D Q$ in patients from $E G$ and $C G$

The results reaffirm the hypothesis of traction therapy as a successful addition to basic therapy in the treatment of patients with LDD.

Discussion. The results from the study clearly show that both treatment protocols yielded favourable results and reduced both static and dynamic pain as well as improved the quality of life of the patients. The results of the EG are superior to those of the CG. The lasting decrease in static and dynamic pain in patients from EG leads to increased mobility of the individuals, due to far less pain while being active $(15,16)$. We relate the obvious superiority, regarding pain reduction, of the protocol used in EG with traction therapy's specific impact over the main causes of pain. This more pronounced effect is due to the decompression of afferent nociceptive conductors in the area of impact and also because of subsequent permanent muscle relaxation and unblocking of intervertebral joints.

Traction therapy is the only conservative method that is applied on local level pathogenically (2). The topographical anatomic changes that emerge as a result of the reduces pressure of the intervertebral disc on the anterior internal venous plexus and the posterior longitudinal ligament lead to decrease of the venous and cerebrospinal fluid stasis, reduction of root and intervertebral ligament swelling $(4,9)$. Due to those changes the irritation of the venous nociceptors and the meningeal branch of the spinal nerve (sinuvertebral nerve) is reduced, i.e. the pain trigger mechanism is eliminated. There are also indications of recovery in the mobility of the lumbar mobile segments and elimination of the blockages in the intervertebral joints.

Conclusions. Both treatment protocols improve significantly the condition of the patients, but the addition of traction therapy yields superior result as evident from the assessment in both groups.

The results from this study prove that the inclusion of traction therapy in a complex physiotherapeutic program benefits patients with lumbar disc disease in terms of reduced pain syndrome and improved quality of life. The proper application of traction therapy has its place in the complex treatment of lumbar disc disease.

\section{REFERENCES}

1. Гатев С., Банков С., Бусаров С. Ръководство по физикална терапия, Медицина и физкултура, 1992, с 83-86; с 175-176

2. Гечев Г., Екстензионно лечение и профилактика на дисковата болест, МФ София 1984, с 16-25, 45-59.

3. Гечев Й., Основи на общата вертебрология. Акад.изд. “проф. Марин Дринов”; изд. “Вион” София, 2001.

4. Гиниятуллин Н.И, Гавришев С.В, Гиниятуллин М.Н, Механотерапия. Тракционная терапия, Медицина. Москва 2013, с64-98

5. Костадинов. Д. Л. Николова. С. Банков. П. Слънчев. Физикалните фактори в комплексното лечение и рехабилитация на някои често срещани заболявания, С., Мед. физк.. 1975

6. Миланов Ив, Неврология учебник, Медицина и физкултура 2012,с 78-478

7. Миланов, И. Болка в неврологичната парктика София, Медицина и физкултура, 2009, 367c 
8. Михайлова М, Тодоров Т,Лочева В. „Целесъобразност в приложението на екстензионната терапия при лечението на пациенти с поясна дискова болест “„Варненски медицински форум“, брой 1'2015

9. Петров П. Поясно-дискова болест: Медицина и физкултура, София , 1980

10. Рязкова М, Кирова И., Физикална терапия - обща и специална част, АРСО, 2002, с 19-50, $206-208$.

11. Тодоров Т. Проучване ефекта на мануалната терапия при цервикокраниални и цервикални блокажи., дис. труд за кандидат на мед.науки 1989г.

12. Andersson GBJ. The Epidemiology of Spinal Disorders. In Frymoyer JW (ed.) The Adult Spine: Principles and Practice. Philadelphia, Lippincott-Raven, 1997, pp. 93-141

13. Balagué F, Mannion AF, Pellisé F, Cedraschi C. Non-specific low back pain. Lancet 2011; 379:482-491.

14. Battie, M. C. \& Videman, T. Lumbar disc degeneration: epidemiology and genetics. J. Bone Joint Surg. Am. 88 (Suppl. 2), 3-9 (2006). 145.

15. Beattie PF, Nelson RM, Michener LA, Cammarata J, Donley J. Outcomes after a prone lumbar traction protocol for patients with activity-limiting low back pain: a prospective case series study. Arch Phys Med Rehabil. 2008.89: 269-274.

16. Diab AA, Moustafa IM. Lumbar lordosis rehabilitation for pain and lumbar segmental motion in chronic mechanical low back pain: a randomized trial. J Manipulative Physiol Ther.2012.35: 246-253

17. Marketos SG, Skiadas P. Hippocrates: the father of the spine surgery. Spine 1999; 24:1381-1387.

18. Roland M, Fairbank J., The Roland-Morris disability questionnaire and the Oswestry disability questionnaire.SPINE Volume25, Number 24, pp 3115-3124@2000, Lippincott Williams \& Wilkins, Inc. 